\title{
Influence of the heat treatment on the quality of ivy gourd (Coccinia grandis)
}

\author{
Thaís Inês M Souza; Cândido A Costa; Milton NC Chauca
}

Universidade Federal de Minas Gerais (UFMG), Montes Claros-MG, Brazil; thais_marquess@hotmail.com; candido-costa@ufmg.br; miltonc9@hotmail.com

\begin{abstract}
Ivy gourd is an underutilized vegetables found in the North of Minas Gerais State-Brazil. It is mainly consumed raw as salad. Pickling fruits can enhance the commercial exploitation of this species. However, no information on the processing techniques of the ivy gourd fruits in Brazil is found in literature. The objective of this study was to evaluate the quality parameters in the production of pickled ivy gourd. The treatments consisted of three bleaching times ( 3,6 and 9 minutes), using a completely randomized design, with seven replicates. We evaluated the traits: instrumental analyzes of $\mathrm{pH}$, color, total titratable acidity, soluble solids, texture and sensorial affective tests. The $\mathrm{pH}$ is within the indicated range (below 4.5) and the bleaching time influenced the color and texture alteration since the sample under 3-minute bleaching presented a greater tendency for green and greater firmness. For the sensory analysis, no significant difference related to sensory scoring was noticed; in relation to mode value, we concluded that the 6-minute sample was more preferable, though. For titratable total acidity and soluble solids analyses, no significant differences between the samples was noticed, considering that both parameters were within the standard when compared to other literature. We concluded that heat treatment influenced only the texture and color intensity and the preserved product showed good acceptability.
\end{abstract}

Keywords: Pickles, underutilized vegetable, processing.

\section{RESUMO}

Influência do tratamento térmico na qualidade de maxixinho (Coccinia grandis) em conserva

O maxixinho é uma das hortaliças não convencionais encontradas no Norte de Minas Gerais, sendo consumido principalmente como salada crua. Uma forma de consumo que pode potencializar a exploração comercial desta espécie é a conserva. Entretanto, não existe informação sobre o processamento do maxixinho na forma de conserva no Brasil. Assim, o objetivo do presente trabalho foi elaborar picles de maxixinho e avaliar parâmetros de qualidade na produção de maxixinho em conserva. O experimento constou de três tratamentos, sendo eles a variação do tempo de branqueamento (3, 6 e 9 minutos). Foi empregado o delineamento inteiramente casualizado, com sete repetições. Foram avaliadas as características: análises instrumentais de $\mathrm{pH}$, cor, acidez total titulável, sólidos solúveis, textura e testes sensoriais afetivos. Observou se que o pH está dentro do indicado (abaixo de 4,5) e que o tempo de branqueamento influenciou na alteração da cor e da textura pois a amostra conduzida sob branqueamento de 3 minutos apresentou maior tendência ao verde e maior firmeza. Para a análise sensorial, não houve diferença significativa das notas, mas em função do valor da moda conclui-se que a amostra de 6 minutos teve maior preferência. Para as análises de acidez total titulável e sólidos solúveis, não houve diferença significativa entre as amostras, sendo que ambos os parâmetros se apresentaram dentro do padrão quando comparados com outras literaturas. Pode-se concluir que o tratamento térmico influenciou apenas na textura e na intensidade da cor e a conserva apresentou boa aceitabilidade.

Palavras-chave: Picles, hortaliça não convencional, processamento.

Received on May 11, 2016; accepted on June 12, 2017

C occinia grandis is one species of Cucurbitaceae family originated from the Southeast Asia, popularly known in Brazil as "maxixinho", small gourd, little cucumber and baby watermelon. It can be consumed in natura as salads and even cooked. It is commercialized in outdoor markets, also being used as medicinal plant (Souza et al., 2014).

In the North part of Minas Gerais, it is grown by small farmers, which commercialize its fruits on a small scale, in general (Brandão et al., 2011) .
The fruit is berry type, size from 3 to $6 \mathrm{~cm}$, approximately. For each 100 $\mathrm{g}$ of fresh material, the fruit presents: water $(93.5 \mathrm{~g})$, protein $(1-2 \mathrm{~g})$, fat $(0.1 \mathrm{~g})$, minerals $(0.5 \mathrm{~g})$, fiber $(1.6 \mathrm{~g})$, carbohydrates $(3.1 \mathrm{~g})$, calcium $(40.0$ $\mathrm{mg})$, phosphorus $(30.0 \mathrm{mg})$, iron $(1.4$ $\mathrm{mg})$, thiamine $(0.07 \mathrm{mg})$, riboflavin $(0.08 \mathrm{mg})$, niacin $(0.7 \mathrm{~g})$, ascorbic acid $(15.0 \mathrm{mg})$ and carotene $(156.0 \mu \mathrm{g})$ (Ramachandran \& Subramaniam, 1983).

Ivy gourd is considered an underutilized vegetable, since it is one of the vegetables which was once largely consumed by the population, and due to a change in feeding behavior had its economic and social expression reduced, losing market space for other vegetables (Brasil, 2010). However, the underutilized vegetables have great cultural importance, since they are more rustic and widely adapted to Brazilian environmental conditions and also show as good nutritional characteristics as the conventional vegetables.

However, the consumption of vegetable species which were implemented in Brazil to meet the 
new market standards is higher than the consumption of the underutilized species (Junqueira \& Luengo, 2000).

Ivy gourd, in natura, is a perishable product, which deteriorates easily, being necessary new forms of conservation. Thus, it is fundamental to provide to consumers alternatives of product presentation which preserve flavor and quality for a longer time (Nascimento et al., 2011).

Thus, studies on better use of ivy gourd in human feeding source are necessary. The production of this vegetable preserved is indicated since, this can stimulate the consumption, increase the shelf life, with appreciation of the actual use of these local foods.

Pickles is the product prepared with the edible parts of fruits and vegetables with or without peel, either natural or fermented, submitted to an appropriate technological processing in order to ensure the conservation (ANVISA, 1977).

Pickled ivy gourd represents a new way to increase the consumption of this vegetable, besides having low production cost and a simple operation technique. It is also an alternative for an off-season consumption, guaranteeing the vegetable conservation, adding value and, consequently, generating more income for agribusiness, favoring the small producers (Nascimento et al., 2011).

Currently considering the competitive markets, the success of the product not only depends on processing and economic viability, but also sensory quality. Therefore, it is essential to consider these factors during the development of new products (Camargo et al., 2007).

In preserving food production, several steps make the processing flowchart. One of the steps is bleaching which consists of heating the product in boiling water for a few minutes, following rapid cooling. Bleaching time can vary from 1 to 10 minutes, according to the species to be processed (Silva, 2000).

Considering that no pieces of information on the pickling-type ivy gourd can be found in literature, the aim of this study was to make ivy gourd pickles and evaluate parameters of quality in the production of the preserved ivy gourd.

\section{MATERIAL AND METHODS}

The experiment was carried out at Instituto de Ciências Agrárias of Federal University of Minas Gerais, Montes Claros, from February to March, 2014.

The ivy gourd used for the processing technique was obtained in Horta Não Convencional at UFMG. The authors used unripe fruits, with standard size and color: intense green and 6-cm length, approximately. These vegetables were washed in running water, sanitized with sodium hypochlorite $(50 \mathrm{ppm} / 10$ minutes) and rinsed under running water.

After sanitization of the fruits, the authors evaluated three different bleaching times (3, 6 and 9 minutes). Then, the fruits were packed in glass pots and liquid medium was added. The medium was prepared using $60 \%$ water, $35 \%$ alcohol vinegar, $3.5 \%$ sodium chloride, $1.5 \%$ sugar and condiments. Afterwards, the authors made heat treatment in water bath for 15 minutes followed by cooling, for sterilization of the pickles. The pickles were stored at room temperature for analyses. The following traits in the liquid medium were analyzed: $\mathrm{pH}$, color, total soluble solids and total titratable acidity. Using the pickled fruits, the authors analyzed the instrumental texture and sensory acceptability. These analyses were performed after reaching $\mathrm{pH}$ balancing, after seven days.

The $\mathrm{pH}$ was analysed at room temperature, approximately $25^{\circ} \mathrm{C}$, using digital potentiometer ( $\mathrm{pH}$ meter) with silver chloride electrode (model PH 21-02 Hanna Instrument), previously calibrated. The Instituto Adolfo Lutz (1985) rules were used.

Total soluble solids content was measured using a refractometer BIOBRIX, model 2WAJ, and expressed in ${ }^{\circ}$ Brix. Titratable acidity was quantified through the amount of sodium hydroxide used according to analytical standard of Adolf Lutz Institute (1985). All these analyses were done in triplicates.

The texture was determined using a TA XT Express texture analyzer (Stable Micro Systems). This equipment, coupled to software, provides directly shear force $(\mathrm{N})$ exerted during compression. The authors used a probe type "Blade Set". The samples were put into the texture analyzer and read in triplicate, following the parameters: pre-test speed of $5.0 \mathrm{~mm} \mathrm{~s}^{-1}$; test speed of $3.0 \mathrm{~mm} \mathrm{~s}^{-1}$; post-test speed of 10.0 $\mathrm{mm} \mathrm{s}^{-1}$; distance from the starting point of $10 \mathrm{~mm}$.

Color was evaluated using a colorimeter (Minolta, model CR400/410). The reflectance of the chromaticity coordinates "L" (brightness), "A" (tonalities) and "b" (saturation) was directly read, using Hunter-Lab scale. The ivy gourd samples were placed in Petri dishes and submitted to reading on the colorimeter. The authors used the CIELAB scale and the samples in triplicate submitted to the colorimeter.

The treatments consisted of three bleaching times (3, 6 and 9 minutes), with 7 replicates, totalizing 21 plots. Each plot consisted of one glass pot with 18 fruits. The experimental design used was completely randomized blocks.

Consumer sensory was evaluated, using 30 non-trained consumers.

The consumers evaluated the parameters: appearance, aroma, taste and texture, using a structure 9-point hedonic scale, basing on extremes 1) "I greatly disliked" and 9) "I really liked it". The hedonic scale is used to measure the food preference of a population, and reports the pleasant and unpleasant states in the body.

The grade averages given by the panelists were submitted to the analysis of variance and Tukey test, 5\% of probability. The statistical analysis was done using the software R. In order to complete the presentations and the interpretation of the results, modal value and standard deviation of the grades attributed to each treatment were calculated.

\section{RESULTS AND DISCUSSION}

No statistical difference was 
observed ( $\mathrm{p} \leq 0.05)$ for $\mathrm{pH}$ (3.30 to 3.31), soluble solids (4.84 to $\left.4.89^{\circ} \mathrm{Brix}\right)$ and total titratable acidity ( 0.85 to $0.89 \%$ ) of the syrup of ivy gourd pickle, in relation to bleaching time.

The authors could observe that the ivy gourd pickle showed $\mathrm{pH}$ value around 3.30, within the established standards, since according to Brazil (1999) the preserves which were artificially acidified, in general, show $\mathrm{pH}$ lower than 4.50 .

Oliveira (2014), studying pickled mini corn, verified that the balance $\mathrm{pH}$ of the preserves ranged from 3.44 to 3.90 . Raupp et al. (2008) emphasized that acidification process of the preserves is a way to guarantee food security of these foods. The heat treatment applied to the pickles can change $\mathrm{pH}$ value of the preserves. Fennema et al. (2010) observed a decrease in $\mathrm{pH}$ in spinach cream during heat processing. The authors believe that the result to the thermal degradation of glutamine for the formation of pyrrolidone carboxylic acid, which causes acidity, increases. However, in this study, the authors did not observe any influence of bleaching time on $\mathrm{pH}$ in the preserves.

The values for soluble solids content ranged from 4.84 to $4.89^{\circ}$ Brix. Such values are statistically similar, not being influenced by the treatments, though.

Oliveira (2014) found values which the combination of heat treatment with

ranged from 5.5 to $6.0^{\circ}$ Brix for organic pickled mini corn. The mentioned author also highlights that for fruits and vegetables, these solids are salts and sugars and that the concentrations of these solids depend on maturation, biosynthesis process or even the degradation of polysaccharides.

For total titratable acidity, the values found were close to $0.80 \%$. Such values are higher than the ones obtained by Reis et al. (2006) for japanese cucumber in natura which ranged from 0.035 to $0.077 \%$ in sodium hydroxide and also to the ones observed by Silva et al. (2009) for 'Caipira' type cucumber ( 0.12 to $0.13 \%$ ). Such differences are due to the acidification processing of the preserves.

In relation to fruit texture of ivy gourd pickle, the authors observed significant difference due to the effect of bleaching time, so that a variation of the softness of the product could be noticed. Values of $32.84 \mathrm{~N}, 14.42 \mathrm{~N}$ and $7.82 \mathrm{~N}$ were observed for preserves of 3, 6 and 9 minutes, respectively, considering that the 3-minute preserves showed to be statistically different from the other ones. The authors also observed that the preserves produced in 6 and 9 minutes showed greater softness whereas the 3 -minute preserves resulted in greater firmness.

The texture of the product changes when it is submitted to heat treatment. The authors could verify that this

Table 1. Average values of luminosity coordinates (L), intensity (-a) and intensity of ivy gourd fruits (Coccinias grandis) (b) according to three bleaching times. Montes Claros, UFMG, 2014.

\begin{tabular}{lccl}
\hline \multirow{2}{*}{ Minutes } & \multicolumn{3}{c}{ Color coordinates } \\
\cline { 2 - 4 } & $\mathbf{L}^{*}$ & \multicolumn{1}{c}{$\mathbf{b}^{*}$} & $\mathbf{- a}^{*}$ \\
\hline 3 & $45.66 \mathrm{a}$ & $20.05 \mathrm{a}$ & $3.87 \mathrm{a}$ \\
6 & $44.62 \mathrm{a}$ & $19.16 \mathrm{a}$ & $3.83 \mathrm{ab}$ \\
9 & $45.24 \mathrm{a}$ & $19.28 \mathrm{a}$ & $3.25 \mathrm{~b}$ \\
\hline
\end{tabular}

Averages followed by the same letter in the column do not differ by Tukey test, $\mathrm{p} \leq 0.05$.

Table 2. Average, set, medium and scoring standard deviation values of sensory analysis of pickle ivy gourd (Coccinia grandis), related to three different bleaching times. Montes Claros, UFMG, 2014.

\begin{tabular}{lcccc}
\hline Minutes & Average & Set & Medium & Standard deviation \\
\hline 3 & $6.53 \mathrm{a}$ & 7 & 7 & 2.05 \\
6 & $6.60 \mathrm{a}$ & 8 & 7 & 1.56 \\
9 & $6.57 \mathrm{a}$ & 7 & 7 & 1.65 \\
\hline
\end{tabular}

Averages followed by the same letter in the column do not differ by Tukey test, $\mathrm{p} \leq 0.05$. parameter was influenced by bleaching time. Dutra et al. (2007) found similar trend during the analysis of texture of preserved peppers. These authors mentioned above also highlight that this change is due to the change in cellular structure during heating.

According to Ni et al. (2005), during the preserves production, heat treatments are used and these treatments result in loss of texture integrity significantly. Goldoni \& Goldoni (2001) highlight that this change in texture is caused by the decomposition of the pectin of the product by its own enzymes, or even by enzymes released by bacteria, yeast or fungi.

For the instrumental color analysis, a significant difference was observed only for intensity criterion ( $\mathrm{a}^{*}$ ), showing that a change in color was related to bleaching time (Table 1).

Luminosity coordinate $\left(\mathrm{L}^{*}\right)$ showed values close to 45.0. Silva et al. (2009) found higher luminosity values ranging from 60.0 to 63.0 in pickled peeled cucumber. Darker color for ivy gourd was noticed when compared to pickled cucumber. Considering color as a criterion for choosing the product: the darker the product is the greater is its depreciation by the consumer.

For saturation $\left(b^{*}\right)$, the authors did not observe any difference among the treatments, considering that all the values were positive showing shades closer to yellow color. Intensity $\left(\mathrm{a}^{*}\right)$ showed statistical difference, allowing highlighting the 3 and 6 -minute preserves which presented greater tendency to green. This indicates that with shorter bleaching time (lower exposure to temperature), less color changes occur.

Evaluating acceptance test for the preserves through the sensory analysis using the hedonic scale, the authors verified no significant differences $(\mathrm{p} \leq 0.05)$ for scores given by the panelists (Table 2).

Although no statistically significant difference was noticed, the authors could conclude that the 6-minute-bleaching preserves had the best acceptability, since modal value of the score gave by 30 panelists was 8 , with a relatively lower standard deviation when compared to 
the other treatments. This fact indicates that the 6-minute-bleaching preserves obtained greater frequency of scores 8 and values closer to this score.

Santos \& Valle (2005) report that the sensory quality of a product can be determined according to how much the product appearance and attractiveness influence the consumer choice. The authors verified that the average values were close to 7 on hedonic scale (I liked regularly), representing a desirable scale region, resulting in good acceptability.

\section{REFERENCES}

ANVISA. 1977. Resolução - CNNPA n ${ }^{\circ}$ 14, de 15 de julho. Disponível em http://www.anvisa. gov.br/anvisalegis/resol/ 14_77.htm.

BRASIL. 1999. Ministério da Saúde. Anvisa. Resolução no 362, de 29 de julho de 1999. Diário Oficial da União (DOU), 22 nov. 1999. Disponível em: <http://www.anvisa.gov.br/ legis/ resol/17_99rdc.htm>. Acesso em: 12 dez. 2015.

BRASIL. 2010. Ministério da Agricultura, Pecuária e Abastecimento. Manual de hortaliças não-convencionais. Brasília: Mapa/ACS, 92p. http://www.paginarural. com.br/artigo/2172/voce-ja-ouviu-falar-emhortalicas-nao convencionais-ja-pensou-emcome-las.

BRANDÃO, AA; COSTA, CA; CAVALCANTI, TFM; SANTOS, BC; SILVA, JR. 2011. Comercialização e produção de hortaliças por agricultores familiares no Norte De Minas Gerais. In: $51^{\circ}$ CONGRESSO BRASILEIRO DE OLERICULTURA, 2011. Anais eletrônico... Viçosa-MG.

CAMARGO, GA; HAJ-ISA, N; QUEIROZ, MR. 2007. Avaliação da qualidade de tomate seco em conserva. Revista Brasileira de Engenharia Agrícola e Ambiental, 11: 521-526.

DUTRA, AS; FURTADO, AAL; DELIZA, R; FERREIRA, JCS. 2007. Cinética da degradação da textura de pimentas em conserva. Boletim CEPPA 25: 267-274.

FENNEMA, OR; DAMODARAN, S; PARKIN, KL. 2010. Química de Alimentos de Fennema, $4^{\mathrm{a}}$ ed. Editora: Artmed, 194p.

INSTITUTO ADOLFO LUTZ. 1985. Normas Analíticas do Instituto Adolfo Lutz. v. 1: Métodos químicos e físicos para análise de alimentos, 3. ed. São Paulo: IMESP, p.27-28.

JUNQUEIRA, AH; LUENGO, RFA. 2000. Mercados diferenciados de hortaliças. Horticultura Brasileira 18: 95-99.

GOLDONI, JS; GOLDONI, CL. 2001. Fermentação lática de hortaliças e azeitonas. In: AQUARONE, E; BORZANI, W; SCHMIDELL, W; LIMA, UA (eds). Biotecnologia industrial: biotecnologia na produção de alimentos. São Paulo: Blucher. p.269-304.

NASCIMENTO, AMCB; NUNES, RGFL; NUNES, LAPL. 2011. Elaboração e avaliação química, biológica e sensorial de conserva de maxixe (Cucumis anguria L.). Revista ACTA Tecnológica 6: 123-136.

NI, L; LIN, D; BARRETT, DM. 2005. Pectin methylesterase catalyzed firming effects on low temperature blanched vegetables. Journal of Food Engineering 70: 546-556.

OLIVEIRA, LF. 2014. Conservas de minimilho (Zea mays, L.) orgânico: Processamento e aceitação sensorial. Revista Verde de Agroecologia e Desenvolvimento Sustentável 9: 271-277.

RAMACHANDRAN, K; SUBRAMANIAM, B. 1983. Scarlet gourd, Coccinia grandis, littleknown tropical drug plant. Economic Botany 37:380-383.

RAUPP, DS; GARDINGO, JR; MORENO, LR; HOFFMAN, JPM; MATIELLO, RR; BORSATO, AV. 2008. Minimilho em conserva: avaliação de híbridos. Acta Amazonica, 38: 509-516.

REIS, KC; ELIAS, HHS; LIMA, LCO; SILVA, JD; PEREIRA, J. 2006. Pepino japonês (Cucumis sativus 1.) submetido ao tratamento com fécula de mandioca. Ciência Agrotecnologia 30: 487-493.

SANTOS, HPD; VALLE, RHP. 2005. Influência da sanificação sobre a qualidade do melão "Amarelo" minimamente processado: parte II. Ciência e Agrotecnologia, 29: 1034-1038.

SILVA, FT. 2000. Recomendações técnicas para o processamento de hortaliças congeladas. Rio de Janeiro: Embrapa Agroindústria de Alimentos, 14p.

SILVA, VA; RIBEIRO, FC; SOUZA, IF; COSTA, FB; PUSCHMAN, R; LOTRETO, MDS. 2009. Análise físico-química de pepino caipira minimamente processado. In: XX CONGRESSO BRASILEIRO DE ECONOMIA DOMÉSTICA. Anais eletrônicos... Fortaleza.

SOUZA, TIM; COSTA, CA; CHAUCA, MNC. 2014. Desenvolvimento e avaliação da qualidade de maxixinho em conserva (Coccinia grandis). In: CONGRESSO BRASILEIRO DE OLERICULTURA, 53. Anais... Palmas: $\mathrm{ABH}$. 